\title{
Experiences of music listening among rugby players at North-West University
}

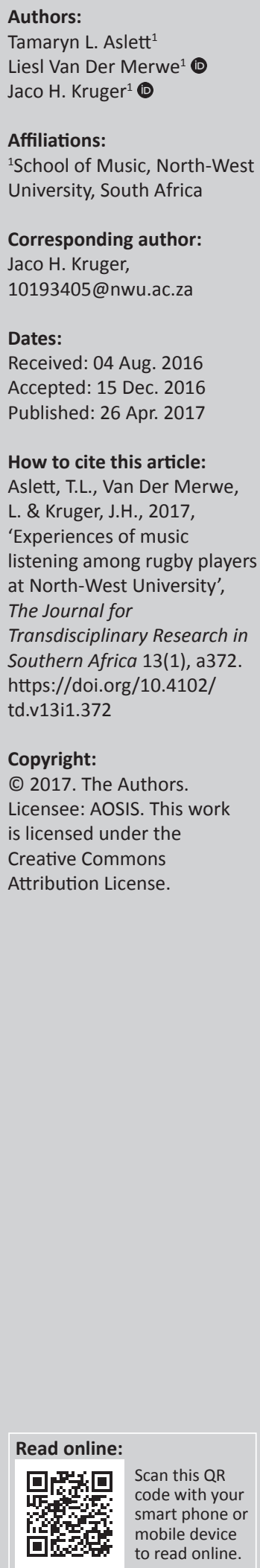

This article documents a study that investigated the reasons why a group of student rugby players habitually listen to music as part of their pre-match routine. The investigation followed a hermeneutic phenomenological approach that allowed the players to verbalise their personal music listening experiences. The investigation links the music listening practices of the players with the concept of musical experience as an innate human capacity directed towards general well-being. For the players, well-being is a basic condition of happiness and optimism. Achieving and maintaining this condition draws on the emotive qualities of musical sound patterns, as well as the powerful, socially situated meanings of song lyrics. Consequent states of mind conceptualise a rewarding existence by integrating experiences in sport as well as in music. Directed towards rugby practice, the study found that music listening is an informal, individual activity that involves the use of earphones. The sense of personal isolation this induces is a prerequisite for generating focus as well as controlled energy, a state of mind regarded as essential for effective participation in rugby. The pervasive use yet informal application of this strategy by rugby players points to an officially undervalued psychological resource. This finding has implications for fuller exploitation and incorporation of music listening into rugby training programmes.

\section{Introduction}

It has become a common practice in professional sport to integrate physical training with mental preparation under the guidance of sport psychologists. This links with a focus in sport research on a diversity of psychological interventions, including the uses and functions ${ }^{1}$ of music in human life. Although our current understanding of the musical human (Homo musicus ${ }^{2}$ ) is intricate, there is a timeless awareness in history of the role of music in the integration of mind and body. This is widely utilised in trance behaviour (Rouget 1985) and discussed famously by Plato who conceptualised an integrated system of physical training and 'musical' education for young Greeks 'to ensure a proper harmony between energy and initiative on the one hand and reason on the other' (Plato 1987:176). Music (mousicē) not only included musical performance, but also the recitation of poetry as well as proficiency in philosophical debate, and as such constituted a comprehensive education. Plato argued accordingly that musical 'rhythm and harmony penetrate deep into the mind and take a most powerful hold on it' (1987:163). This perceptive observation of a basic psychological function of music seems to have retained limited value in contemporary society where music is regarded as non-pragmatic 'art', and any connection between music and the physical nature of sport is implausible. Yet rugby players, like a diversity of other athletes, may increasingly be observed listening to music prior to matches, usually by means of earphones connected to a variety of small sound devices. ${ }^{3}$ The obvious question is why they do so, and thus the objective of this discussion is to explore prematch music listening experiences among a small group of students at North-West University's Rugby Institute. ${ }^{4}$ In so doing, this report hopes to provide some direction towards incorporating music listening routines into formal rugby training programmes.

\section{Research on music listening and sport}

Research in this field typically focuses on the functions of music listening as part of general psychological preparation for participation in sport events (Eckard 2012; Hutchinson et al. 2011;

1.Function 'essentially refers to a person's reaction to a musical event as it is experienced or remembered; use is the way meanings are incorporated into planning and realising a musical event' (Kaemmer 1993:142).

2.Linked with Homo narrans (the storytelling human; see e.g. Niles 2010) and Homo symbolicus (the symbolic human; Deacon 1998), Homo musicus is characterised by an innate capacity to exploit musical experiences for adaptive purposes.

3.This was, for example, the case prior to the Rugby World Cup final (2015) at Twickenham, London, when members of the Australian team were shown on television stepping down from their bus, listening to music through earphones.

4.The institute was founded in 2000. It promotes rugby on the Potchefstroom campus and trains players and officials for professional careers (http://www.nwu.ac.za/rugbyinstitute). 
Karageorghis \& Priest 2012a; Lane, Davis \& Devonport 2011; Terry et al. 2012). Music listening has been shown to accompany training (Karageorghis \& Priest 2008; Stieg 2011), enhance performance (Bernardi, Porta \& Sleight 2006; Karageorghis \& Priest 2012b; Lim et al. 2009), reduce the rate of perceived exertion (Knight \& Whitehead 2012; Shaulov \& Lufi 2009) and promote perseverance (Eckard 2012; Stieg 2011).

These studies tap into long-standing research on the relationship between musical experience and psychological well-being (e.g. Lee et al. 2012; Logid 2011; Shinn 2011; Vuoskoski \& Eerola 2012). Generally speaking, investigations focus on the beneficial effects triggered by music such as physical relaxation, emotional self-regulation (Nicol 2010:352) and intense states of affection (Lowis 2010:86). In a sport environment, listening to music is 'a complex phenomenon, involving psychological, emotional, neurological and cardiovascular changes, with behavioural modifications of breathing' (Bernardi et al. 2006:445). However, this subject is under-researched, particularly from a phenomenological perspective (Belcher \& Haridakis 2013:375; Bishop 2010:35). Sport psychology studies often lack data relating to athletes' lived experiences of music (Sorenson et al. 2008:3), especially their pre-competition music listening routines. Such research could provide insight into the personal value athletes attach to music listening, and so contribute towards the ongoing development of psychological training programmes.

\section{Research design}

The investigation on which this report is based (Aslett 2014), followed an interpretive qualitative approach, generally designed to reveal the ways humans encounter and interact with their social worlds (Merriam 2002:4). Specifically utilising a hermeneutic phenomenology (see Butler-Kisber 2010:51; Creswell 2013:79; Van Manen 1990:25), the inquiry analysed, interpreted and compared the lived or conscious experiences (so-called texts of life) of individual rugby players, not so much to identify some apparent 'essence' as to conceptualise them (Creswell 2013:76; Merriam 2002:4, 7; Van Manen 1990:4). Discussions accordingly centred around three basic phenomenological issues, namely perceptions, thoughts and emotions (Moustakas 1994:95), that were elicited by means of reflective essays and interviews. The ATLAS.ti 7 qualitative data analysis and research software was utilised to organise the data into codes, categories and themes (see Creswell 2013:184-185).

The group comprised 10 participants, ${ }^{5}$ most of whom played in the same team. They consented to personal interviews. ${ }^{6}$ These interviews initially were open-ended, but it soon became clear that the participants were not used to verbalising their music listening experiences. To generate 'thick' or detailed descriptions from them, the interviews consequently

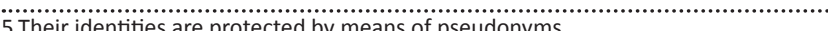
6.The interviews took place at Potchefstroom from February to April 2014. Some participants also corresponded by e-mail during November and December 2012, as well as November 2015 became semi-structured, following the design of Smith, Flowers and Larkin (2009). Information was elicited by means of descriptive, narrative, contrasting, evaluative, circular and comparative questions and prompts, and they typically included the following: Tell me about the role music plays in your life; When first did you listen to music before a game?; Where do you prefer to listen to music prior to a game?; Imagine not feeling motivated or energised before a game, and describe how music listening might affect you; What would it be like if you no longer could listen to music before a game?; What kind of music do you listen to before a game?; and Describe the feelings that various kinds of music stimulate in you.

\section{Emergent themes}

Four themes emerged from the investigation. The uses of music listening prior to rugby matches need clarification in relation to the (1) general musical experiences of participants and (2) well-being these experiences promote. Such clarification is a prerequisite for interpreting participants' descriptions of the psychological conditioning that music listening is perceived to induce. These descriptions involve the themes of (3) focus as well as (4) controlled energy.

\section{Participant perceptions of musical experience and well-being}

Musical experience is a concept that refers to all mental operations and physical actions involved in composing, performing, listening to and talking about music. Well-being involves the states of bodily and psychological health of groups and individuals.

The basic state of well-being induced by music in participants generally was described by them as feeling better or happiness. Given the complex, ambiguous nature of emotional states, some participants struggled to verbalise their feelings. Barend simply noted that he listens to music regularly, but that he does not know why: 'It's just nice'. André was more explicit, although similarly laconic, and remarked that he is 'crazy' about music. Danie in turn explained that certain types of music give him goosebumps. Jacobus linked these kinds of experiences to the commonly perceived seat of the emotions: 'In my heart, it (music) is like, literally, a gladness in my life, a joy'.

These explanations all in some way point to the inborn human capacity to process sound, and specifically to musical sound as a form of sensual and emotional experience. Emotions may be viewed as a dynamic mind-brain-body state (Cross \& Tolbert 2009:30) which arises in response to environmental conditions and social experiences. Put differently, emotions involve 'bodily co-operation with an image, a thought, a memory - a co-operation of which the individual is aware' (Hochschild 1979:551). Given that the striving for happiness is a core human concern, its realisation by means of music listening may be an ongoing practice. Thabo explained that he listens to music all the time. It not 
only gives him pleasure but also motivates him: 'Yes, you forget (bad things). You think only about how good it (the match) is going to be, and not of all the other stuff that bothers you'. To Ruan, music listening also is a strategy aimed at making his life better in the long term. In particular, it is a reaction to experiencing 'stress', feeling bored or just generally having a 'bad day'. This function was confirmed by other participants. André explained that, 'Sometimes, if I'm very stressed, I will listen to a nice song'. According to Jacobus, 'If you don't have a very good day, then it (music listening) helps a lot'. Danie agreed: 'Yes, I think it does. If a person feels bad (on a certain) day, then it makes you feel better', while Jason explained that listening to songs 'builds him up' by transforming negative thoughts into positive ones.

Of further interest is Jason's remark that music listening allows him to focus, 'chill' and 'just be myself'. Eben indicated similarly that music listening is an 'escape' from his daily problems, and that it enables him to set his 'mind straight'. These explanations relate to the capacity of the arts to induce virtual realities, to create imaginary worlds where life is contemplated and possible solutions are explored free from constraints (see 'Focus' section). Such flights of the imagination have potential to feed back into daily existence as adaptive strategies. Eben remarked that he often finds himself getting 'caught up in (song) lyrics' and comparing his 'dreams and ideals with the lyrics' of a particular artist. Similarly, for Jacobus, lyrics are not stories that only connect with the composer, but which can also relate to the lives of listeners. As we elaborate in the 'Controlled energy' section, music listening by participants is a theme in their coming of age narratives in which they implicitly present themselves as young, upcoming rugby players establishing themselves in the world.

While the creation of imaginary worlds in art is universal, these worlds are ultimately shaped by personal circumstances and preferences in culture-specific settings. The interviews uncovered a range of connotative or situational musical meanings that are linked to social experiences. These meanings are elicited 'when music originally heard as part of a significant experience causes one to recall later the feelings accompanying the original experience' (Kaemmer 1993:118; also see Boutcher \& Trenske 1990:174; DeNora 2000:66). Rouget (1985) discusses the role of music in trance behaviour and finds that its efficacy in inducing trance primarily derives from its iconic function - in other words, not so much from its inherent musical qualities as its sonic embodiment of a spiritual entity, social experience or network. He cites philosopher Jean-Jacques Rousseau who described the emotional trance that the famous cattle herding song Ranz des vaches invoked in Swiss troops because it recalled 'their country, their former pleasures, their youth, and their whole manner of living, exciting in them a bitter sorrow for having lost all that' (Rouget 1985:168).

\section{Francois remarked in this regard that:}

'Look, if I have a bad day, then I will put on, like, happy music. Like, I listen to Afrikaans - Bok van Blerk, for example. He plays good music, so I put it on to feel better.'
Van Blerk is an icon of certain forms of Afrikaner identity. $\mathrm{He}$ is a composer, singer and film actor who expresses the experiences and emotions of a large sector of young people who are struggling to position themselves within a turbulently changing socio-political landscape. As we explain in the 'Controlled energy' section, well-known performers of other styles of popular music have similar iconic status for certain participants.

The connotative meanings of music to participants also recall patterns of socialisation. Jason noted that:

'If you listen to a certain song, it actually reminds you of the year that song (was produced) and you listened to it, and you were on vacation somewhere with friends, and it just brings memories back.'

This experience was also identified by other participants, and it even extends to sport participation, since specific songs were linked with memories of rugby games. Jason explained that, 'In a rugby game or something - you think back to that game where you may be played well or you tackled someone hard or something like that'. To Barend, 'It brings back memories of happy times, of how you played (rugby) with your friends from school, and so on'.

The explanation of the first two themes underscores that, in order to clarify the reasons why participants listen to music as part of their pre-match routines, it is necessary to account for the general value of music in their lives. To them, musical experiences are an element of existence which generate states of mind that unravel and plan life. These experiences help to induce well-being (in the basic form of optimism and happiness), often by invoking meanings linked with enjoyable social experiences.

\section{Focus}

The themes of focus and controlled energy reveal an awareness among players of the importance of a holistic approach to match planning. Eben remarked that preparation is both physical and mental, and that listening to music is therefore 'a necessity' for him. For Jacobus, music listening similarly is a conscious, personal strategy - 'the way in which I want to prepare myself for a game'.

Focus essentially involves 'getting into the zone'. This refers to focused or 'narrowed' attention which may improve muscle control and reduce feelings of anxiety (Karageorghis, Terry \& Lane 1999:721; Williams et al. 2011:2). Ruan explained that, 'For me, it's not like I must listen to music to get into the zone, but it does definitely help'. Jean remarked that the wellknown song Conquest of paradise helps him to focus before a game. The song came to his attention because it is often played at international and local rugby and cricket matches ${ }^{7}$ :

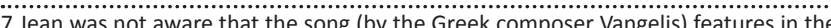
. eponymous film by Ridley Scott (1992), and that it conjures up heroic images of vision, perseverance, exploration, conquest and conflict. The lypics are in so-called pseudo-Latin and, apart from a brief reference to domination, do not contribute as strongly to the emotional effect of the song as its musical features and associated film images (https://en.wikipedia.org/wiki/Conquest_of_Paradise_(song)) 
'I used to have problems focusing and switching on before a game, and this song gets me into a state where I just focus on the game and my job in the game, without letting anything distract me.' (Jean)

Focus is generally achieved by means of auditory detachment from extraneous noise. Ruan explained that listening to music using headphones can block out ambient sound:

'You don't hear, like, the noise of the bus [transporting the team] or noise from other people. It cuts you off. Like, if I want to concentrate, say now before the game, then [I become] very isolated from the rest of the world, from all the people around me.'

Players seek a sense of isolation and may listen to music at some distance from the rest of team. Danie noted that that he goes 'to one side and sits alone'. This strategy helps to suppress negative thoughts and emotions. All players similarly strive to avoid distraction prior to a game. Jason remarked emphatically that it is necessary to put 'everything that does not concern the game out of your head' and that, 'As soon as you put on the music, you will get more focus'. Ruan explained likewise that it is important not to allow 'other things' to 'bother' him. In fact, $80 \%$ of the participants stated unequivocally that the focus generated by listening to music helps them to drive thoughts not related to the match from their mind. For Jason, listening facilitates the development of 'tunnel vision' - the capacity to focus on the game ahead and ignore unwanted mental interference. Jean, who used to struggle to concentrate before a game, discovered that music listening enables him to 'switch on', that is, to stop his attention from drifting: 'Usually when I listen to (a) song, my mind doesn't wander to things that don't matter at the moment. I only think about the game nothing can distract me'.

While focusing by means of music applies generally to prematch routines, it specifically also enables the visualisation of a game. Such mental imaging is employed by $70 \%$ of the players who indicated that focusing prepares them for their specific roles and responsibilities. Danie envisions what he is going to do on the field, while Jacobus already imagines himself playing the game. André noted that:

\footnotetext{
'Since every position has its own specific job on the rugby field, so you listen to music and then you think only about what you must do. You go through the type of movements that you must do - through the different names of movements - just to make sure you have [internalised] everything'.
}

\section{Controlled energy}

Controlled energy, from the perspective of participants, refers to the capacity of music listening for affect regulation - to control contrasting yet interdependent states, namely a sense of motivation or increased energy, as well as composure. This requirement not only applies to competition but also practices. Danie explained that:

'If you really don't feel like going to practice, and then you listen to music, or you listen to a certain song, then it will just kind of psyche you up to go.'
A particularly fitting description of the link between feelings of restlessness and the energising effect of certain songs was offered by Jacobus who remarked that at times 'something is chasing me, (so) that I now must listen (to music), so that I must go and do something' (i.e. play rugby). Similarly, as soon as Thabo gets into the cloakroom, he listens 'to that music that pumps, that, like, motivates me'. André enjoys selecting music that 'works' him up before a game - that gets his 'adrenaline levels up'. Francois also finds that music 'builds' him prior to a game: 'It also maybe gives me that bit of adrenaline as well. I am crazy about it!' For Eben, 'psychedup music' is what motivates him. Generating a state of motivation obviously is a primary objective of pre-game preparation, and Jean described it as 'a feeling that I am ready to go on the field and do my job the best I can'.

Conversely, reflecting on the possibility of not being able to listen to music before a game, participants argued that this would result in decreased focus and energy. This was verbalised most clearly by Danie who explained that 'It's a mental thing. I think you won't be mentally as prepared as you usually are with music'. This feeling of incomplete preparation would take away his resoluteness and eagerness to play: 'You won't have that urgency in you that makes you want to play - that hunger to play'.

A variety of musical styles play a decisive role in achieving a motivated, energised state of mind. Players not only identified their preference for specific songs but also pointed out the effect of lyrics as well as sound patterns. Song styles exploited for their musical rather than verbal content include club and trance music - pulsating, electronic dance music. When Ruan needs 'a bit more energy', he will listen to club music. Danie in turn explained that he listens to certain songs prior to a game because they 'psyche' him up and provide him with 'extra energy'. For example, the song Russian privjet by Basshunter is 'a very trancy song that, just if you listen to it, it just, it calms you down, but at the same time it just makes you focus and motivates you' ${ }^{8}$

Songs selected primarily for their lyrics were described by Jason as 'motivational', as they may transmit valuable knowledge and instruct him: 'Just play good music that will teach you'. While certain lyrics energise Eben, he noted that their 'passion' is what 'drives' him, and that it is important to him that they should portray triumph: 'Any song with a beat, or strong lyrics that can relate to any kind of victory'. Songs that induce this condition in him include rapper R. Kelly's World's greatest, which compares the artist's expressive skills with the power of natural forces. Not surprisingly, rap songs are especially utilised for their lyrics, although their rhythmic form of delivery is also considered important. Eben explains that the song 8 Mile by Eminem deals with 'someone who is with his back against the wall and must prove the world wrong. That he only has success as option, and the struggles (mentioned in the song) could refer to hard work [...] where all the strenuous (rugby) practices are a struggle, but well worth the effort.'

8.The song is primarily instrumental. It is characterised by repetitive, strongly pulsating, electronically produced rhythmic patterns. 
This theme also characterises another rap song, namely Remember the name (Fort Minor). According to Jason, the lyrics of this song 'come alive' in him. They portray a core image in rap culture, namely that of the budding artist (often from the underclass) rising in the world against many odds. This is also an expression of the coming of age experience. It is a core concern in human narrative, and it describes the young undergoing physical, cognitive and emotional development in preparation for their expected adult roles (Booker 2004). Remember the name and 8-Mile accordingly offer images of personal struggle and growth, and express the desire for success and recognition (hence the title Remember the name).

Coming of age experiences in narrative engage the protagonist in a diversity of social interactions, one of which involves romantic relations (Booker 2004). The love song Time to say goodbye, as performed by Sarah Brightman, is one of Jason's favourites. He explains that he likes it because 'It's the way she sings, and the way the lyrics are, and the music; just everything - it just works together'. It is not improbable that this comment verbalises the subconsciously generated image of the heroine - of the popular, beautiful female singer who is idealised as an object of desire. Although the concept of libido commonly is associated with sexual desire, 'it can also be desexualized and viewed as an undifferentiated energy that is at the basis of such mental processes as thinking, feeling, sensation, and intuition' (http://medical-dictionary. thefreedictionary.com/libido). The songs Remember the name and 8 Mile resound with images of bursting energy, and it is worth recalling Jacobus's reference to feelings of restlessness that drive him to music listening and rugby playing. Put differently, the need for love and the impulse for personal development and self-assertion (in this case, as an athlete) originate from the same well-spring. DeNora $(2000: 62,63,70)$ notes in this regard that music is 'a device or resource to which people turn in order to regulate themselves as aesthetic agents, as feeling, thinking and acting beings in their day-today lives'. It may help them to recognise and construe their true selves. Musical experiences allow the individual to achieve self-growth and gain knowledge. This has a bearing on self-esteem (Elliott \& Silverman 2014:382), and self-esteem that is in place - along with issues of control, competency and achievement - is a cornerstone of well-being (Laukka 2007:217).

While a condition of increased energy is obviously important in sport, it may also be counterproductive. Jason explained that:

'If you are [too] psyched up at the beginning of the game, you tend to make errors. Whereas at the beginning of the game you should actually be more focused and relaxed so that you can get confidence in yourself throughout the game and then build yourself up.'

André also pointed out that a player 'must never be (too) worked up, because then you do stupid things on the field'. Therefore, while there is general agreement on the importance of enhanced emotional energy prior to a game, this condition must be tempered; in other words, the ideal mental and physical state of the athlete is that of controlled energy. Ninety percent of the participants indicated accordingly that music also has a calming effect on them. This is an affirmation of the primordial capacity of music to arouse as well as tranquilise. Musical performance involved in trance behaviour is well-known to promote as well as terminate states of heightened emotion (Rouget 1985:73). Danie's experience is that music helps him relax before an encounter: 'You're a little bit nervous, and maybe the music helps to, like, calm you down'. Composure prepares Jean for a game by 'chilling' him. Jason prefers 'classical' music to calm him down: 'For instance a song like Time to say goodbye (performed by) Sarah Brightman - that's one of my favourite songs actually. Listening to that song just makes me calm down'. Danie's experience of the song Russian privjet as inducing arousal as well as calmness seems unusual since there is a tendency among players to avoid energetic club music when they want to achieve a condition of composure. Nevertheless, the function of one particular song to create a state of controlled energy is also attributed by Jean to Conquest of paradise. Apart from its energising effect, the song also invokes 'a certain type of calmness':

'A feeling that I am ready to go on the field and do my job the best I can, feeling ready and switched on. When I don't listen to music, I feel like my mind is elsewhere and I am not in control of my ability to focus on what matters.' (Danie)

\section{Conclusion}

The purpose of this report has been to clarify the practice of music listening prior to rugby games. Its main finding is that it is an informal, individual activity that involves the use of earphones. This technology is of essential importance, as it enables a required state of isolation which effects 'zoning' or focusing. It generates increased energy yet simultaneously induces composure, leading to a state of balanced or controlled energy. It also promotes visualisation of the roles players are required to perform on the field. These functions of music listening currently are an important psychological resource that is exploited only informally by rugby players. Our recommendation is for the incorporation and development of music listening routines in official training programmes.

The investigation links the uses of music listening with musical experience as an innate human capacity directed towards general well-being. Returning to Plato's perceptive observations, it is necessary to underscore his notion that a 'harmoniously adjusted' mind and body will 'produce a character that is self-controlled and brave' (Plato 1987:175). The basic condition of happiness that music listening generates in participants draws on the inherent, emotive power of musical sound patterns as well as the powerful, socially situated meanings of song lyrics. These qualities and meanings appear to function as sociobiological triggers in the powerful, impulsive drive towards personal self-assertion in social settings. There is a link between popular (musical) culture and the competitive strategies of the young rugby players. Their stories offer images of young men rising in the 
world as competent social actors. They specifically present the rugby player as young folk hero, in accordance with the status of the icons of popular music performance. This merger of identities undermines stereotypical notions of the athlete and artist. The mental state of the rugby player often is reduced to that of simple aggression. In fact, participants in this study have been shown to express a range of emotions, mental states and reflective conditions that link with musical expression. It seems that rugby balls and popular songs do go together, and that their attached identity forms cannot be fixed in accordance with the stereotype of the aggressive athlete or sensitive artist - they are a nuanced and multifaceted resource intuitively applied across diverse domains of human existence.

\section{Acknowledgements Competing interests}

The authors declare that they have no financial or personal relationships which may have inappropriately influenced them in writing this article.

\section{Authors' contributions}

The investigation on which this article reports was carried out by T.A. under supervision by L.V.D.M. The research report was reworked into article form by J.K.

\section{References}

Aslett, T.L., 2014, 'Exploring lived experiences of music listening among rugby players: A hermeneutic phenomenology', unpublished MMus dissertation, North-West University, Potchefstroom.

Belcher, J.D. \& Haridakis, P., 2013, 'The role of background characteristics, musiclistening motives, and music selection on music discussion', Communication Quarterly 61(4), 375-396. https://doi.org/10.1080/01463373.2013.776986

Bernardi, L., Porta, C. \& Sleight, P., 2006, 'Cardiovascular, cerebrovascular, and respiratory changes induced by different types of music in musicians and nonmusicians: The importance of silence', Heart 92(4), 445-452. https://doi. org/10.1136/hrt.2005.064600

Bishop, D., 2010, 'Boom boom how": Optimising performance with music', International Review of Sport and Exercise Psychology 6(1), 35-47.

Booker, C., 2004, The seven basic plots: Why we tell stories, Continuum, London.

Boutcher, S.H. \& Trenske, M., 1990, 'The effects of sensory deprivation and music on perceived exertion and affect during exercise', Journal of Sport and Exercise Psychology 12, 167-176. https://doi.org/10.1123/jsep.12.2.167

Butler-Kisber, L., 2010, Qualitative inquiry: Thematic, narrative and arts-informed perspectives, Sage, London.

Creswell, J.W., 2013, Qualitative inquiry and research design: Choosing among five approaches, 3rd edn., Sage, Los Angeles, CA.

Cross, I. \& Tolbert, E., 2009, 'Music and meaning', in S. Hallam, I. Cross \& M. Thau (eds.), The Oxford handbook of music psychology, pp. 24-44, Oxford University Press, Oxford.

Deacon, T.W., 1998, The symbolic species: The co-evolution of language and the brain, W.W. Norton, New York.

DeNora, T., 2000, Music in everyday life, Cambridge University Press, Cambridge. https://doi.org/10.1017/CBO9780511489433

Eckard, L., 2012, 'Dis waarna SA se swemmers luister', Beeld, 6 August, p. 3.

Elliott, D.J. \& Silverman, M., 2014, Music matters: A philosophy of music education, 2nd edn., Oxford University Press, New York.

Hochschild, A., 1979, 'Emotion work, feeling rules and social structure', American Journal of Sociology 85, 551-575. https://doi.org/10.1086/227049

Hutchinson, J.C., Sherman, T., Davis, L., Cawthon, D., Reeder, N.B. \& Tenenbaum, G., 2011, 'The influence of asynchronous motivational music on a supramaximal exercise bout', International Journal of Sport Psychology 42(2), 135-148.
Kaemmer, J., 1993, Music in human life, University of Texas Press, Austin, TX.

Karageorghis, C. \& Priest, D.L., 2008, 'Music in sport and exercise: An update on research and application', The Sport Journal 11(3), viewed 14 January 2012, from http://www.thesportjournal.org/article/music-sport-and-exercise-updateresearch-and-application

Karageorghis, C.I. \& Priest, D.L., 2012a, 'Music in the exercise domain: A review and synthesis (part I)', International Review of Sport and Exercise Psychology 5(1), 44-66. https://doi.org/10.1080/1750984X.2011.631026

Karageorghis, C.I. \& Priest, D.L., 2012b, 'Music in the exercise domain: A review and synthesis (part II)', International Review of Sport and Exercise Psychology 5(1), 67-84. https://doi.org/10.1080/1750984X.2011.631027

Karageorghis, C.I., Terry, P.C. \& Lane, A.M., 1999, 'Development and initial validation of an instrument to assess the motivational qualities of music in exercise and sport: The Brunel music rating inventory', Journal of Sports Sciences 17, 713-724. https://doi.org/10.1080/026404199365579

Knight, A. \& Whitehead, J.R., 2012, 'Music and exercise: Does creating an expectancy of enjoyment increase reported enjoyment?', Pamukkale Journal of Sport Sciences $3(3), 63-77$.

Lane, A.M., Davis, P.A. \& Devonport, T.J., 2011, 'Effects of music interventions on emotional states and running performance', Journal of Sports Science and Medicine 10, 400-407.

Laukka, P., 2007, 'Uses of music and psychological well-being among the elderly', Journal of Happiness Studies 8, 215-241. https://doi.org/10.1007/s10902-0069024-3

Lee, E.J., Bhattacharya, J., Sohn, C. \& Verres, R., 2012, 'Monochord sounds and progressive muscle relaxation reduce anxiety and improve relaxation durin chemotherapy: A pilot EEG study', Complementary Therapies in Medicine 20 409-416. https://doi.org/10.1016/j.ctim.2012.07.002

Lim, H.B.T., Atkinson, G., Karageorghis, C.I. \& Eubank, M.R., 2009, 'Effects of differentiated music on cycling time trial', International Journal of Sports Medicine 30(6), 435-442. https://doi.org/10.1055/s-0028-1112140

Logid, J., 2011, 'The healing power of art: Is it just for patients?', Creative Nursing 17(3), 118-119. https://doi.org/10.1891/1078-4535.17.3.118

Lowis, M.J., 2010, 'Emotional responses to music listening: A review of some previous research and an original, five-phase study', Journal of Applied Arts and Health 1(1), 81-92. https://doi.org/10.1386/jaah.1.1.81/1

Merriam, S.B., 2002, Qualitative research in practice: Examples for discussion and analysis, Jossey-Bass, San Francisco, CA.

Moustakas, C., 1994, Phenomenological research methods, Sage, Thousand Oaks, CA.

Nicol, J.J., 2010, 'Body, time, space and relationship in the music listening experiences of women with chronic illness', Psychology of Music 38, 351-367. https://doi. org/10.1177/0305735609351914

Niles, J.D., 2010, Homo narrans: The poetics and anthropology of oral literature, University of Pennsylvania Press, Philadelphia, PA.

Plato., 1987, The Republic, 2nd edn., Penguin, London.

Rouget, G., 1985, Music and trance: $A$ theory of the relations between music and possession, University of Chicago, Chicago, IL.

Scott, R. (Dir.), 1992, 1492: Conquest of Paradise (film), Paramount Pictures, Los Angeles, CA.

Shaulov, N. \& Lufi, D., 2009, 'Music and light during indoor cycling', Perceptual \& Motor Skills 108(2), 597-607. https://doi.org/10.2466/pms.108.2.597-607

Shinn, L., 2011, 'Sound it out', Natural Health 41(6), 22.

Smith, J.A., Flowers, P. \& Larkin, M., 2009, Interpretive phenomenological analysis: Theory, method and research, Sage, London.

Sorenson, L., Czech, D.R., Gonzalez, S., Klein, J. \& Lachowetz, T., 2008, 'Listen up! The experience of music in sport - A phenomenological investigation', The Online Journal of Sport Psychology 10(2), viewed March 2013, from http://www. athleticinsight.com/Vol10lss2/Music.html

Stieg, B., 2011, 'The healing power in your iPod', Men's Health 26(1), viewed March 2012, from http://ehis.ebscohost.com.nwulib.nwu.ac.za/eds/detail?sid=981729 c8-d9e6-419b-8ecd-1f27734a4de8\%40sessionmgr4\&vid=3\&hid=16\&bdata=JnN pdGU9ZWRzLWxpdmU\%3d\#db=f5h\&AN=56636659

Terry, P.C., Karageorghis, C.I., Saha, A.M. \& D’Auria, S., 2012, 'Effects of synchronous music on treadmill running among elite triathletes', Journal of Science and Medicine in Sport 15, 52-57. https://doi.org/10.1016/j.jsams.2011.06.003

Van Manen, M., 1990, Researching lived experience: Human science for an action sensitive pedagogy, State University of New York Press, New York.

Vuoskoski, J.K. \& Eerola, T., 2012, 'Can sad music really make you sad? Indirect measures of affective states induced by music and autobiographical memories', Psychology of Aesthetics, Creativity, and the Arts 6(3), 204-213. https://doi. org/10.1037/a0026937

Williams, B., Gluck, D., Thompson, B. \& Simon, P., 2011, Rhythms of the game: The link between musical and athletic performance, Hal Leonard, Milwaukee, WI. 